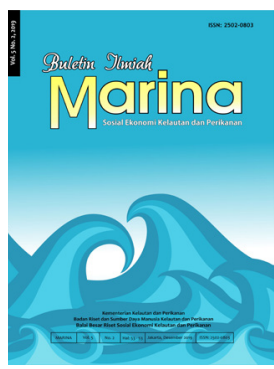

BULETIN ILMIAH MARINA

SOSIAL EKONOMI KELAUTAN DAN PERIKANAN

http://ejournal-balitbang.kkp.go.id/index.php/mra

p-ISSN: 2502-0803

e-ISSN: 2541-2930

Nomor Akreditasi: 10/E/KPT/2019

\title{
MANAJEMEN RISIKO USAHA PENANGKAPAN IKAN LAUT DENGAN ALAT TANGKAP GILLNET DI PULAU BAAI, KOTA BENGKULU
}

\section{Risk Management of Fishing Activity Using Gillnet Fishing Gear in Baai Island, Bengkulu}

\author{
*Febi Yulianti, Ketut Sukiyono, dan Satria Putra Utama \\ Jurusan Sosial Ekonomi Pertanian Fakultas Pertanian Universitas Bengkulu \\ JI. W.R. Supraman Kandang Limun Bengkulu Telp. 073621190
}

Diterima tanggal: 31 Oktober 2019 Diterima setelah perbaikan: 6 November 2020

Disetujui terbit: 21 Desember 2020

\begin{abstract}
ABSTRAK
Bisnis perikanan selalu dihadapkan dengan resiko ketidakpastian, termasuk upaya penangkapan ikan menggunakan alat tangkap Gilnett. Identifikasi sumber risiko, dampak dan strategi risiko penting, tidak hanya untuk bisnis tetapi juga bagi pemerintah untuk merancang intervensi yang tepat. Penelitian ini bertujuan untuk (1) mengidentifikasi sumber risiko, (2) menganalisis probabilitas dan efek risiko, dan (3) menganalisis strategi manajemen risiko. Pemilik atau kapten kapal dari dua puluh tujuh unit kapal yang menggunakan alat tangkap Gilnett disensus dan diwawancarai dengan kuesioner. Data yang dikumpulkan meliputi karakteristik responden, sumber risiko, dampak risiko, aspek operasional, harga dan pasar bisnis perikanan yang dilakukan. Analisis deskriptif dan analisis manajemen risiko diterapkan untuk menjawab tujuan penelitian. Hasil penelitian menunjukkan bahwa sumber risiko yang terjadi paling besar adalah risiko operasional pada sumber risiko cuaca yang tidak dapat diprediksi, ketidakpastian hasil tangkapan, dan permodalan. Pada usaha penangkapan ikan laut di Kota Bengkulu, nilai probabilitas berdasarkan lama melaut dan nilai tangkapan ikan, yaitu sebesar $32,64 \%$ dan $48,40 \%$. Nilai dampak risiko berdasarkan lama melaut dan nilai tangkapan sebesar Rp9.948.578,25 dan Rp548.793.316,42. Hasil studi menyimpulkan bahwa strategi yang dapat dilakukan dalam mengelola risiko, yang meliputi (a) pemanfaatkan informasi cuaca seoptimal mungkin, (b) membiasakan menabung ketika hasil melimpah, (c) perluasan fishing ground di luar daerah tangkapan tradisionalnya, (d) ketepatan area pengkapan (fishing ground), (e) perpanjangan lama melaut, dan (f) diversifikasi vertikal (hilirisasi) hasil tangkapan.
\end{abstract}

Kata Kunci: manajemen risiko; perikanan tangkap; gilnett; Pulau Baai; Bengkulu

\section{ABSTRACT}

Fishery business is always faced with uncertainty risks, including fishery business using Gilnett fishing gear. The identification of sources of risk, impacts and risk strategies are important not only for businesses but also for the government to design appropriate interventions. This research aimed to (1) identify the sources of risks, (2) analyze the probabilities and risk effects, and (3) analyze the risk management strategies. The owner or captain of the twenty-seven vessel units who use the Gilnett fishing gear were censused and interviewed with a questionnaire. Data was collected includes the characteristics of the respondents, sources of risks, risk impacts, operational aspects, prices and markets of the business of fishing. Descriptive analysis and risk management analysis were applied to answer research objectives. The results of the study indicate that the greatest source of risk is an operational risk on sources of unpredictable weather risks, uncertainty about catches, and capital. Fishing activity in Bengkulu City, the probability value is based on the fishing trip period and the catch value is $32.64 \%$ and $48.40 \%$. The value of the risk impact is based on the fishing trip period and the value of the catch is IDR 9,948,578.25 and IDR 548,793,316.42. The results of the study conclude that strategies that can be carried out in managing risks including (a) utilizing the most optimal weather information, (b) getting 
used to saving when the abundant results, (c) expanding fishing ground outside the traditional catchment area, (d) accuracy of the catching area (fishing ground), (e) prolongation of fishing day, and (f) vertical diversification (downstreaming) of catches.

\section{Keywords: risk management; capture fisheries; gilnett; Baai Island; Bengkulu}

\section{PENDAHULUAN}

\section{Latar Belakang}

Target utama dari setiap usaha penangkapan ikan dengan menggunakan jenis alat tangkap apapun adalah memperoleh hasil tangkapan ikan sebanyak mungkin. Hasil tangkapan ini diharapkan dapat menutupi semua biaya yang dikorbankan serta mendapatkan keuntungan baik berupa ikan tangkapan maupun hasil penjualannya. Kenyataan di lapangan menunjukkan bahwa usaha penangkapan ikan tidak selalu memperoleh hasil dan nilai jual seperti yang diharapkan. Berbagai literatur menunjukkan bahwa usaha penangkapan ikan laut sebagaimana juga usaha di bidang pertanian merupakan salah satu usaha yang memiliki tingkat kegagalan cukup tinggi. Kegagalan dan risiko usaha ini selalu dan harus dihadapi oleh nelayan, termasuk nelayan di pelabuhan Pulai Baii Kota Bengkulu. Nelayan dalam usahanya menangkap ikan menghadapi banyaknya rintangan serta dihadapkan pada risiko dan ketidakpastian. Dilihat dari segi produksi, risiko yang dihadapi para pelaku usaha (nelayan) adalah hasil tangkapan yang sangat bervariasi dan kadang tidak sesuai dengan hasil yang diharapkan. Permasalahan dan risiko ini dihadapi oleh semua nelayan tidak terkecuali bagi nelayan yang menggunakan alat tangkap Gillnet.

Gillnet (jaring insang) merupakan salah satu alat tangkap yang digunakan oleh pelaku usaha perikanan tangkap di Pulau Baai Kota Bengkulu. Gillnet, menurut Tangke (2011), adalah alat tangkap yang direntangkan di suatu perairan pada kedalaman tertentu dan ukuran mata jaring tertentu, sehingga ikan yang menabrak jaring akan terjerat pada mata jaring. Sebagian besar nelayan di Bengkulu khususnya di Pelabuhan Pulau Baii Bengkulu, menggunakan alat tangkap Gillnet (KKP, 2018). Data ini menginformasikan banyak nelayan yang menggantungkan hidup dan penghidupannya pada hasil tangkap dengan menggunakan Gillnet. Perikanan tangkap, dengan menggunakan alat tangkap apapun, selalu dihadapkan pada berbagai risiko dan ketidakpastian. Mullon, Fréon, \& Cury (2005) menjelaskan bahwa resiko dan ketidakpastian ini, termasuk ketidakpastian biologis yang melekat, dipengaruhi oleh faktor eksternal (seperti perubahan kondisi lingkungan atau perubahan permintaan atau perkembangan teknologi) dan di bawah interaksi banyak pemain (nelayan atau negara), tetapi juga ketidakpastian yang terkait dengan faktor ekonomi dan pasar. Oleh sebab itu, kajian risiko dan manajemen risiko pada usaha penangkapan ikan dengan menggunakan alat tangkap Gillnet menjadi bijak dan penting untuk dilakukan.

Risiko merupakan kemungkinan kejadian yang berpotensi merugikan atau suatu ketidakpastian suatu keadaan yang dihadapi seseorang atau perusahaan dan memberikan dampak yang merugikan (Purwitasari, 2011; Siahaan, 2007). Darmawi (1990) dan Djohanputro (2008) menjelaskan bahwa risiko dihubungkan dengan kemungkinkan terjadinya atau ketidakpastian yang dapat berakibat buruk (kerugian) yang tak diinginkan serta keberlanjutan usaha. Lebih lanjut, Darmawi (2006) menambahkan bahwa risiko adalah penyebaran hasil aktual dari hasil yang diharapkan. Ada tiga unsur penting dari sesuatu yang dianggap sebagai risiko, yaitu merupakan suatu kejadian, yang mengandung kemungkinan, dan jika terjadi akan mengakibatkan kerugian. Risiko, menurut William \& Heins (1985), juga didefinisikan sebagai suatu variasi dari hasil-hasil yang dapat terjadi selama periode tertentu pada kondisi tertentu. Risiko bisnis dapat dikategorikan menjadi empat jenis, yaitu risiko keuangan, risiko operasional, risiko strategis, dan risiko eksternalitas yang menurut Chen, Chen, Cheng, \& Shevlin (2010), risiko dapat disebabkan oleh faktor eksternal dan internal.

Diskusi di atas menunjukkan pentingnya mengelola resiko. Salah satu alasan pentingnya adalah risiko mengandung biaya yang tentunya tidak sedikit. Di samping itu, risiko menurut Kloman (1992) yang dihadapi oleh perusahaan atau industri adalah risiko yang lebih baru dan lebih dinamis sehingga perlu ditangani secara efektif oleh manajemen risiko yang terkait dengan industri. Di samping itu, risiko dalam suatu organisasi saling terkait erat dan fungsi manajemen risiko harus menangani semua risiko dalam pendekatan yang komprehensif. Definisi manajemen risiko (risk 
management) yang dikemukakan oleh Well-Stam, Lindenaar, Kinderen, \& Bunt (2004); Kasidi (2010); Ehsan, Denis, Kujur, \& Chaudhary (2014); Bahamid, Doh, Al-Sharafi, \& Rahimi (2017) dapat disimpulkan bahwa, manajemen risiko berkaitan dengan menetapkan atau mengidentifikasi tujuan, mengumpulkan informasi yang relevan mengenai sifat masalah dan lingkungan, mengevaluasi biaya dan manfaat dari alternatif menggunakan teknik analitik modern, dan memilih alternatif yang paling konsisten dengan tujuan dan sasaran. Doherty (1982) mengemukakan bahwa proses manajemen risiko dapat direpresentasikan dalam bentuk respons terhadap pertanyaan-pertanyaan berikut: (a) Apa masalahnya? (Identification); (B) Berapa besarnya masalah? (Measurement); dan (c) Apa yang dapat dilakukan tentang masalah tersebut? (Decision). Leung, Muraoka, Nakamoto, \& Pooley (1998) berpendapat bahwa teknik analisis keputusan digunakan dalam merancang beberapa rencana pengelolaan objektif untuk pelagis longlining di Hawaii. Sanchirico, Smith, \& Lipton (2008) menerapkan analisis portofolio untuk mengoptimalkan berbagai manajemen stok di Teluk Chesapeake. Sementara itu, penelitian Leal (2008) mengungkapkan strategi lain untuk mengatasi variabilitas yang tidak dapat diprediksi yang belum secara formal diidentifikasi sebagai manajemen risiko digunakan oleh peserta perikanan, seperti pembentukan koperasi nelayan untuk berbagi risiko produksi. Review tentang manajemen risiko pada perikanan tangkap dibahas dengan detail oleh Sethi (2010).

Penelitian ini bertujuan

untuk mengidentifikasi sumber-sumber risiko, menganalisis probabilitas dan dampak risiko, serta menganalisis alternatif strategi penanganan risiko yang dihadapi oleh usaha penangkapan ikan dengan menggunakan alat tangkap Gillnet. Hal ini penting karena dengan teridentifikasinya risiko yang dihadapi para pelaku usaha penangkapan ikan laut dengan Gillnet di Kota Bengkulu, maka usaha penangkapan ikan dapat dijalankan secara berkelanjutan dengan meminimalkan kemungkinan dan dampak yang akan terjadi.

\section{Pendekatan IImiah}

Penelitian ini dilakukan di Pelabuhan Pulau Baai Bengkulu. Penentuan responden dilakukan dengan metode sensus. Sensus adalah cara atau proses pengambilan data atau penelitian dengan mengambil seluruh elemen populasi yang diteliti (a complete enumeration) (Sukiyono, 2018). Dalam penelitian ini, populasi yang diamati adalah unit kapal dengan menggunakan alat tangkap Gilnett yang menurut BPP (2018) jumlah kapal yang beroperasi di Pelabuhan Pulau Baii berjumlah 27 unit. Seluruh kapten kapal dan atau pemilik kapal tangkap ini dijadikan responden yang selanjutnya dilakukan wawancara dengan bantuan kuesioner yang telah dipersiapkan terlebih dahulu. Dalam penelitian ini, data yang diambil antara lain karakteristik nelayan pemilik kapal, persepsi pemilik kapal terhadap sumber resiko, data terkait yang dengan aspek operasional, pasar dan harga seperti biaya melaut, permodalan, pesaing, permintaan ikan, dan harga jual hasil tangkapan. Analisis data yang dilakukan adalah analisis deskriptif dan analisis manajemen risiko. Sukiyono (2018) mendefinisikan analisis deskriptif sebagai suatu metode dalam meneliti yang tujuannya mendeskripsikan, menggambarkan dan menjelaskan secara sistematis terhadap fenomena yang diteliti.

Analisis manajemen risiko dilakukan melalui tahap identifikasi sumber risiko, pengukuran risiko, pemetaan risiko, dan penanganan risiko. Tahap pertama dalam manajemen risiko adalah identifikasi sumber-sumber risiko (William \& Heins, 1985). Dalam penelitian ini, daftar risiko potensial dikembangkan dan diberikan skor (dari 1 -5) untuk dinilai derajat risikonya oleh responden dengan menggunakan pendekatan kuesioner dan dilengkapi dengan inspeksi atau observasi di lapangan. Sumber-sumber risiko dikategorikan menjadi tiga, yaitu risiko rendah, sedang, dan tinggi berdasarkan rata-rata skor dari responden. Kategori risiko didasarkan pada Wardhono (2005), dengan rumus:

$$
\text { Skala Interval }=\frac{\text { Nilai Maksimum }- \text { Nilai Minimum }}{\sum \text { Kategori }}
$$

Setelah sumber risiko diidentifikasi, pengukuran potensi ukuran kerugian dan kemungkinan terjadi risiko dengan metode z-score, yang dikembangan oleh Roy (1952), seperti yang disarankan Kountur (2008). Z-score adalah skor standar dalam bentuk skor jarak dari kelompok rata-rata dalam unit Deviasi Standar (Base, 2016) dan diperkirakan dengan rumus berikut:

$$
Z=\frac{x-\bar{x}}{S}
$$


dengan $\mathrm{Z}$ adalah nilai peristiwa risiko, $\mathrm{x}$ adalah nilai batas risiko yang dianggap normal atau dapat diterima. S adalah standar deviasi peristiwa risiko dan diperkirakan oleh:

$$
S=\sqrt{\frac{\sum_{i=1}^{n}\left(x_{i}-\bar{x}\right)}{n-1}}
$$

dengan $\bar{x}$ adalah nilai rata-rata peristiwa risiko, adalah nilai peristiwa risiko pada periode $\mathrm{i}$, dan $\mathrm{n}$ adalah jumlah pengamatan. Peristiwa risiko rata-rata diperkirakan menggunakan rumus berikut:

$$
\bar{x}=\frac{\sum_{i=1}^{n} x_{i}}{n}
$$

Selanjutnya, dampak risiko diestimasi dengan mengikuti saran Kountur (2008), yaitu dengan menggunakan metode $V a R$ (Value at Risk). $V a R$ adalah kerugian terbesar yang mungkin terjadi dalam rentang waktu tertentu dan ditimbulkan oleh kejadian berisiko. Zhang, Zhang, \& Zhao (2019) menjelaskan bahwa VaR digunakan untuk menggambarkan potensi kerugian maksimum di bawah tingkat kepercayaan yang diberikan. VaR diestimasi dengan menggunakan rumus sebagai berikut Jorion (2001):

$$
\operatorname{VaR}=\bar{x}+Z\left(\frac{S}{\sqrt{n}}\right)
$$

Pemetaan risiko dilakukan sebelum merumuskan alternatif strategi penanganan risiko. Kountur (2008) menjelaskan peta risiko sebagai gambaran tentang posisi risiko pada suatu peta dari dua sumbu, yaitu sumbu vertikal yang menggambarkan probabilitas dan sumbu horizontal menggambarkan dampak, seperti terlihat pada Gambar 1. Batas antara probabilitas

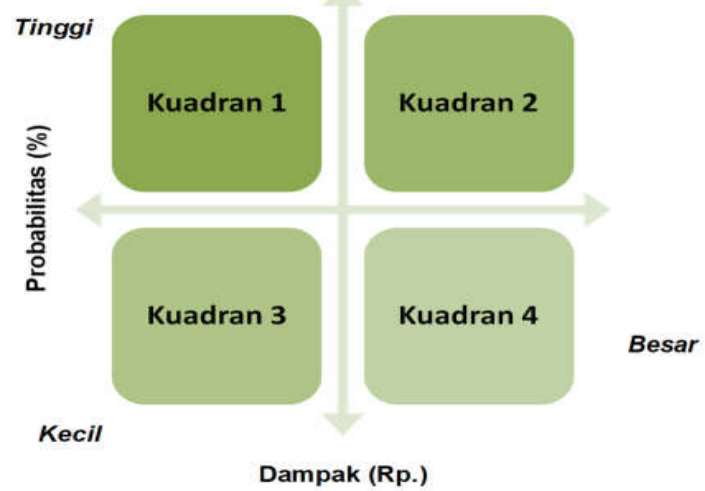

Gambar 1. Peta Risiko.

Sumber: Kountur (2008) atau kemungkinan besar dan kecil ditentukan oleh manajemen. Hal yang sama untuk nilai dampak yang membatasi dampak besar dan dampak kecil ditentukan oleh perusahaan atau nelayan sendiri. Selanjutnya, penentuan batas dari probabilitas besar dan kecil dilakukan dengan menentukan rata-rata dari probabilitas dari kedua sumber risiko (Prahestin \& Harahab, 2018).

Hasil pemetaan digunakan untuk merancang strategi penanganan risiko. Artinya, strategi yang ditawarkan akan dirumuskan berdasarkan posisi masing-masing sumber risiko produksi pada peta risiko. Ada beberapa strategi yang dapat dilakukan untuk menangani risiko, yaitu: (a) Hindari (Avoid): tidak menerima risiko, misalnya keluar dari bisnis atau usaha; (b) Terima (Accept): menerima tingkat risiko dan tidak mengambil tindakan untuk meminimalkannya lebih lanjut; (c) Transfer (Transfer): mentransfer risiko kepada orang lain, misalnya mengggunakan asuransi; serta (d) Mitigasi (Mitigation): mengambil tindakan untuk mengelola risiko secara umum melalui sistem kontrol internal (Booker, 2005). Kountur (2008) mengklasifikasikan menjadi dua strategi utama dalam mengelola risiko, yaitu: (a) Penghindaran Risiko (preventif): strategi preventif dilakukan untuk menangani risiko pada kuadran 1 dan 2 yang tergolong dalam probabilitas risiko besar. Penanganan risiko ini diharapkan akan menggeser posisi risiko yang berada pada kuadran 1 menuju kuadran 3 dan kuadran 2 menuju kuadran 4; serta (b) Mitigasi Risiko: strategi mitigasi digunakan untuk meminimalkan dampak risiko. Risiko yang berada pada kuadran dengan dampak yang besar diusahakan dapat bergeser ke kuadran yang memiliki dampak risiko yang kecil. Strategi mitigasi akan menangani risiko yang berada pada kuadran 2 bergeser ke kuadran 1 dan risiko yang berada pada kuadran 4 bergeser ke kuadran 3 . Perancang strategi pengelolaan risiko dalam penelitian ini akan mengacu pada Kountur (2008).

\section{KARAKTERISTIK NELAYAN}

Usia pelaku usaha penangkapan ikan berkisar antara 22 tahun sampai 70 tahun dengan rata - rata usia adalah 49,33 tahun. Kelompok usia produktif adalah mereka yang berada dalam rentang usia 15 sampai dengan 64 tahun. Usia tersebut berdasarkan kategori umur masih terbilang umur produktif. Pelaku usaha penangkapan ikan laut $100 \%$ hanya dilakukan oleh kaum laki-laki saja. Sedangkan kaum perempuan hanya melakukan pekerjaan yang hanya bisa dilakukan di rumah 
saja. Jumlah anggota keluarga akan sangat berpengaruh pada kebutuhan keluarga. Semakin banyak jumlah anggota keluarga maka akan semakin banyak pula kebutuhan rumah tangganya.

Pendidikan yang ditempuh oleh pelaku usaha penangkapan ikan laut menunjukkan rata-rata pendidikan adalah selama 6,51 tahun. Rata-rata pelaku usaha telah menempuh pendidikan pada jenjang SD dan rata-rata pengalaman usahanya telah berlangsung selama 17,63 tahun. Lama pengalaman usaha akan menggambarkan bentuk ketrampilan dan pengetahuan seseorang dalam melakukan suatu pekerjaan.

Armada kapal yang beroperasi dengan alat tangkap gillnet terbuat dari kayu dengan rata-rata kekuatan 7,25 GT. Armada kapal yang digunakan memiliki panjang berkisar antara 3-15 m dengan lebar antara 2,5 - 5 m. Jumlah anak buah kapal (ABK) rata-rata 5 orang dengan kisaran antara 4 - 15 orang. Jumlah ini sangat bergantung pada ukuran kapal yang dioperasikan. Sementara itu, pengoperasian armada kapal dengan alat tangkap gillnet kebanyakan sebagian besar dengan one day fishing, yaitu berangkat pagi dan baru mendarat sore atau malam hari selepas magrib.

Data survei juga menunjukkan bahwa jarak antara fishing base menuju ke fishing ground kurang lebih ditempuh selama 2 - 4 jam perjalanan. Ada tiga daerah operasi penangkapan yang sering banyak dikunjungi, yaitu (a) Enggano dengan kedalaman 50 meter dan kondisi dasar perairan lumpur berpasir, (b) Padang dan sekitarnya dengan kedalaman 800 meter dan kondisi dasar perairan, dan (c) Teluk Harapan Merpas. Daerah tangkapan ini sangat bergantung pada ukuran kapal dan ukuran mesin dengan data survei menunjukkan bahwa rata-rata ukuran mesin berkisar antara $10-67 \mathrm{PK}$.

\section{IDENTIFIKASI SUMBER-SUMBER RISIKO}

Salah satu fungsi manajemen risiko yang paling kritis mungkin adalah proses identifikasi. Kegagalan untuk mengenali keberadaan satu atau lebih peristiwa potensial dapat mengakibatkan kerugian secara finansial. Pentingnya bisa mengantisipasi keberadaan masalah sebelum terwujud diakui oleh semua orang tetapi sayangnya tidak ada metode ilmiah atau pendekatan sistemik untuk proses identifikasi. Risiko merupakan suatu kemungkinan keadaan yang tidak dapat dipungkiri kapan akan terjadi, baik kemungkinan yang terjadinya bersifat menguntungkan atau bersifat merugikan. Menurut Fahmi (2011), risiko operasional merupakan risiko yang umumnya bersumber dari masalah internal. Risiko ini disebabkan oleh lemahnya manajemen sistem kontrol oleh pelaku usaha. Risiko operasional disebabkan oleh faktor ketidakpastian iklim, ketidakpastian hasil tangkapan, dan faktor-faktor teknis biaya yang berada di luar kontrol setiap pelaku usaha. Hasil identifikasi diperoleh bahwa sumber risiko yang paling tinggi adalah sumber risiko operasional pada sumber risiko cuaca yang tidak dapat diprediksi. Risiko yang memiliki skor di atas 3 dan masuk pada kategori sedang adalah sumber risiko ketidakpastian hasil tangkapan dan permodalan (Tabel 2).

Ketidakpastian hasil tangkapan merupakan risiko yang tinggi karena dengan adanya ketidakpstian tersebut maka para nelayan tidak bisa mempekirakan apakah mereka akan mendapatkan keuntungan atau kerugian. Temuan ini sama dengan penelitian Lindawati \& Rahadian (2016) yang menyebutkan bahwa usaha penangkapan ikan akan selalu dihadapkan pada risiko yang tinggi, akibat dari ketidakpastian nilai tangkapan ikan yang ditangkap per periode tangkap. Di samping itu, nelayan juga dihadapkan pada

Tabel 1. Karakteristik Unit Kapal Tangkap dengan Alat Tangkap Gilnett.

\begin{tabular}{|c|c|c|c|c|c|}
\hline No & Karakteristik & & Rata-rata & Standar Deviasi & Kisaran \\
\hline 1 & Ukuran Kapal (GT) & & 7,25 & 3,87 & $5-28$ \\
\hline 2 & Anak Buah Kapal (orang) & & 5 & 0,83 & $4-15$ \\
\hline 3 & Ukuran Mesin (PK) & & 32,43 & 26,27 & $10-67$ \\
\hline 4 & Jumlah Trip per bulan & & 4 & 6,78 & $4-30$ \\
\hline 5 & Daerah melaut & $\begin{array}{l}1 . \\
2 . \\
3 .\end{array}$ & \multicolumn{3}{|c|}{$\begin{array}{l}\text { Enggano dengan kedalaman } 50 \text { meter dan kondisi dasar } \\
\text { perairan lumpur berpasir } \\
\text { Daerah penangkapan ikan ini dioperasikan di Padang dengan } \\
\text { kedalaman } 800 \text { meter dan kondisi dasar perairan } \\
\text { Teluk Harapan Merpas }\end{array}$} \\
\hline
\end{tabular}

Sumber: Data Primer Diolah, 2019 
Tabel 2. Sumber Resiko Operasional Usaha Penangkapan Ikan dengan Alat Tangkap Gillnet.

\begin{tabular}{lcc}
\multicolumn{1}{c}{ Sumber Risiko } & Skor & Kategori Risiko \\
\hline Risiko Operasional & & Sedang \\
Ketidakpastian hasil tangkapan & 3,3 & Tinggi \\
Cuaca tidak dapat diprediksi & 4,5 & Sedang \\
Kesulitan tenaga kerja & 2,6 & Sedang \\
Permodalan & 3,1 & Sedang \\
Lama waktu menangkap ikan & 2,5 & Sedang \\
Risiko Pasar dan Harga & & Sedang \\
Harga yang diperoleh tidak sesuai & 3,0 & Sedang \\
Harga fasilitas produk naik & 2,9 & Sedang \\
Banyak pesaing & 2,7 & Sedang \\
Harga murah saat produksi banyak & 2,6 & Sedang \\
Kerusakan ikan sehingga mutu produk rendah & 2,6 & Sedang \\
Permintaan pasar terhadap ikan rendah & 2,6 & \\
Daya beli masyarakat menurun & 2,5 & \\
\hline
\end{tabular}

Sumber: Data Primer Diolah, 2019

risiko permodalan yang tinggi. Kebergantungan nelayan kepada pemilik modal atau pemilik kapal untuk melaut menjadi permasalahan tersendiri. Pelaku usaha mendapatkan modal juga alat - alat melaut dengan sistem bagi keuntungan dengan pemilik kapal. Dengan sistem ini, para pemilik kapal tersebut tidak pernah mengenakan bunga kepada kapten kapal dan anak buahnya, hanya saja mereka hanya dapat menerima hasil penjualan ikan yang telah dibeli juga oleh pemilik kapal tersebut. Permodalan juga mempengaruhi seberapa lama para pelaku usaha dapat melakukan perjalanan untuk menangkap ikan. Menurut penelitian Lindawati \& Rahadian (2016), kesulitan permodalan dialami oleh nelayan pada saat terjadi kerusakan mendadak pada mesin atau setelah musim paceklik ketika nelayan hendak mulai melakukan kegiatan penangkapan ikan. Nelayan yang mengalaminya akan melakukan usaha peminjaman uang kepada para agen pembeli hasil tangkapan mereka. Dengan cara tersebut, mereka dapat melakukan usaha penangkapan kembali, meskipun harus menanggung biaya tambahan yang dikenakan oleh para agen sepanjang hutang mereka belum dapat dilunasi. Ke depan, penelitian terkait dengan manajemen risiko, aspek risiko teknik perlu dipertimbangkan sebagai salah satu sumber risiko.
Pada risiko harga atau pasar, sumber risiko paling tinggi dalam kategori sedang, yaitu sumber risiko harga yang tidak dapat diprediksi. Ketidakpastian hasil tangkapan merupakan risiko yang tinggi bagi para nelayan, karena dengan adanya ketidakpastian tersebut maka para nelayan tidak bisa mempekirakan apakah mereka akan mendapatkan keuntungan atau kerugian.

\section{PROBABILITAS DAN DAMPAK RISIKO OPERASIONAL}

Data-data yang digunakan untukmelakukan analisis manajemen risiko adalah data yang diperoleh dari hasil wawancara, dan pengamatan langsung di lapangan. Seperti diungkapkan di atas, kemungkinan terjadinya risiko, diukur dengan metode nilai z-score. Analisis probabilitas risiko operasional dipengaruhi oleh tingkat biaya operasional dan nilai tangkapan normal. Biaya operasional dalam hal ini adalah modal. Dengan demikian, kemungkinan terjadinya risiko operasional pada usaha penangkapan ikan laut di Kota Bengkulu diestimasi dari modal dan nilai tangkapan (Tabel 3).

Hasil penelitian menunjukkan bahwa nilai probabilitas pada lama melaut sebesar $48,40 \%$, sedangkan pada sumber risiko berdasarkan nilai

Tabel 3. Hasil Analisis Probabilitas dan Dampak Risiko Operasional Berdasarkan Lama Melaut dan Nilai Tangkapan.

\begin{tabular}{lccrr}
\hline \multicolumn{1}{c}{ Sumber Risiko } & Probabilitas (\%) & Batas Risiko (\%) & Value at Risk (Rp) & Batas Risiko (Rp) \\
\hline Kesulitan modal melaut & 48,40 & 40,52 & $9.948 .578,25$ & $9.500 .000,00$ \\
Nilai Tangkapan & 32,64 & 40,52 & $528.221 .990,08$ & $510.000 .000,00$ \\
\hline
\end{tabular}

Sumber: Data Primer Diolah, 2019 
tangkapan menunjukkan bahwa nilai probabilitas sebesar $32,64 \%$. Nilai $z$-score digunakan untuk melihat besaran angka pada Tabel $z$ dan untuk melihat posisi sumber risiko produksi tertinggi pada kurva rata - rata distribusi normal. Sumber risiko lama melaut menunjukkan nilai z-score sebesar 0,035 dengan tanda negatif. Angka ini menginformasikan bahwa pada kurva rata-rata distribusi normal berada di sebelah kiri dan nilai 0,035 pada Tabel $z$ menunjukkan angka 0,4840. Nilai ini menunjukkan kemungkinan usaha penangkapan ikan laut di Kota Bengkulu akan mengalami penurunan untuk risiko operasional lama melaut sebesar $48,40 \%$. Untuk sumber risiko nilai tangkapan, nilai $z$-score sebesar 0,45 . Nilai $z$-score tersebut pada Tabel $z$ menunjukkan angka 0,3264 dengan tanda negatif, artinya, posisi risiko berada di sebelah kiri kurva rata-rata distribusi normal. Nilai ini menunjukkan bahwa penurunan operasional nilai tangkapan sebesar $32,64 \%$.

Pengukuran risiko tidak hanya dilakukan pada kemungkinan terjadinya risiko itu sendiri, tetapi juga estimasi dampak dari risiko itu sendiri. Penghitungan atau estimasi terhadap dampak risiko operasional dilakukan untuk mengetahui perkiraan kerugian yang akan diderita para pelaku usaha. Berdasarkan Tabel 2, perolehan nilai $V a R$ untuk setiap sumber risiko berbeda-beda. Nilai $\mathrm{VaR}$ risiko operasional tangkapan lebih besar dari nilai risiko modal, yaitu sebesar Rp528.221.990,08, sedangkan untuk sumber risiko nilai tangkapan sebesar Rp9.948.578,25. Dampak risiko produksi akan dikombinasikan dengan hasil perhitungan analisis probabilitas risiko untuk melihat gambaran posisi masing-masing sumber risiko pada peta risiko.

\section{PEMETAAN RISIKO}

Menurut Kountur (2008), peta risiko memiliki empat kuadran yang memisahkan probabilitas besar dan kecil serta dampak besar dan kecil. Sumbu vertikal dan horizontal dibatasi oleh nilai yang menjadi besaran probabilitas dan dampak risiko. Penempatan posisi sumber-sumber risiko pada peta risiko didasarkan dari hasil analisis probabilitas dan dampak risiko operasional berdasarkan lama melaut dan nilai tangkapan (Tabel 2).

Penentuan batas dari probabilitas besar dan kecil dilakukan dengan menentukan rata-rata dari probabilitas dari kedua sumber risiko (Prahestin \& Harahab, 2018). Jadi batas dari nilai probabilitas risiko operasional usaha penangkapan ikan laut di Kota Bengkulu, yaitu sebesar 40,52\%. Sedangkan batas dampak risiko berdasarkan risiko pada usaha penangkapan ikan laut di Kota Bengkulu ditentukan oleh pelaku usaha itu sendiri (Tabel 2). Dampak yang ditimbulkan oleh sumber risiko melebihi batas yang telah ditentukan pelaku usaha maka dampak ini dianggap besar, sebaliknya jika dampak yang ditimbulkan oleh sumber risiko masih di bawah batas risiko maka risiko dianggap kecil.

Hasil pemetaan sumber-sumber risiko di atas menunjukkan seberapa besar kemungkinan risiko terjadi dan dampak yang akan ditimbulkan oleh risiko. Hasil penelitian menunjukkan bahwa lama melaut berada di kuadran 2. Kuadran 2 ini merupakan sumber risiko krusial dengan probabilitas besar dan dampak besar. Artinya, sumber risiko ini harus segera ditangani, apabila dibiarkan saja maka akan menimbulkan kerugian yang sangat besar. Hasil penelitian pada kuadran 4 merupakan sumber risiko yang memiliki probabilitas kecil dan dampak besar. Jika risiko ini kemungkinan akan terjadi, maka akan menimbulkan dampak yang besar bagi usaha ini. Hasil pemetaan risiko yang telah dilakukan adalah untuk menentukan strategi yang tepat dalam proses penanganan risiko operasional yang dihadapi oleh pelaku usaha penangkapan ikan laut di Kota Bengkulu

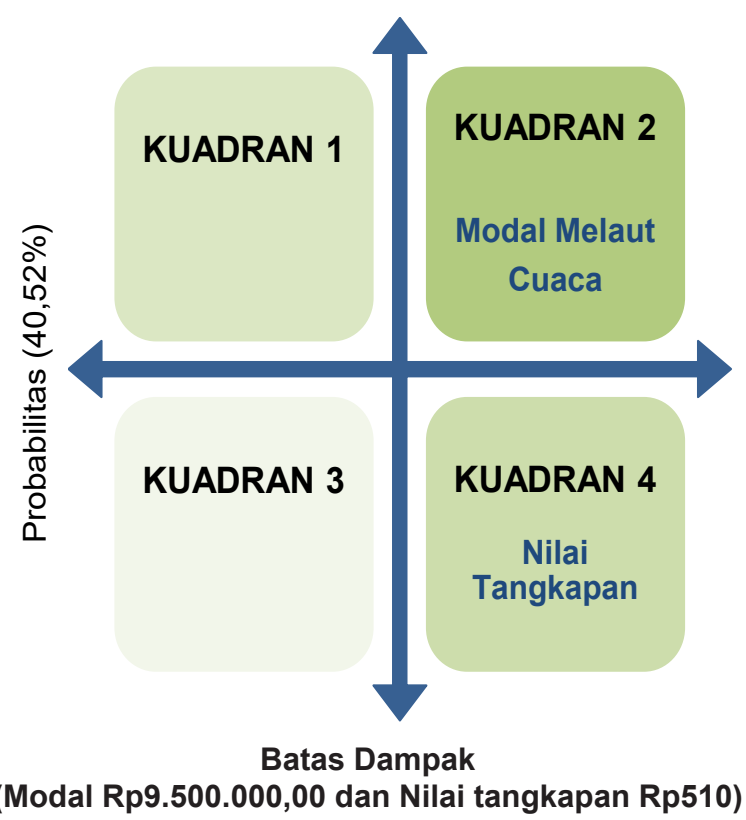

Gambar 2. Pemetaan Sumber Risiko Operasional
pada Kesulitan Permodalan dan
Ketidakpastian Hasil Tangkapan.

Sumber: Data Primer Diolah, 2019 
Berdasarkan sumber risiko yang dianalisis, distribusi pelaku usaha berdasarkan sumber risiko lama melaut dan nilai tangkapan. Distribusi pelaku usaha menurut sumber risiko dapat dilihat pada Tabel 4. Tabel 4 ini menunjukkan bahwa sebagain besar nelayan mengatakan bahwa mereka memiliki kencenderungan yang tinggi untuk mengalami risiako kekurangan modal dan nilai tangkapan dengan dampak yang relatif kecil, seperti yang ditunjukkan pada persentase jumlah nelayan yang ada pada kuadran 1. Sebagian nelayan juga mengatakan bahwa dampak risiko yang ditanggung tinggi, meskipun probabilitasnya cukup rendah akibat dari modal dan nilai tangkapan.

Tabel 4. Distribusi Pelaku Usaha Menurut Sumber Risiko.

\begin{tabular}{lcccc}
\hline \multirow{2}{*}{ Sumber Risiko } & \multicolumn{4}{c}{ Kuadran (\%) } \\
\cline { 2 - 5 } & I & II & III & IV \\
\hline Modal Melaut & 59,26 & 22,22 & 0,00 & 18,52 \\
Nilai Tangkapan & 44,44 & 11,11 & 3,70 & 40,75 \\
\hline
\end{tabular}

Sumber: Data Primer Diolah, 2019

\section{ALTERNATIF STRATEGI PENANGANAN RISIKO OPERASIONAL}

\begin{abstract}
Usulan strategi dirumuskan berdasarkan posisi dari masing-masing sumber risiko produksi pada peta risiko (Gambar 2). Dalam proses manajemen risiko ada dua cara yang harus dilakukan untuk mengatasi adanya risiko, yaitu penghindaran risiko (preventif) dan mitigasi risiko.
\end{abstract}

\section{Penghindaran Risiko (Preventif)}

Penghindaran terhadap risiko dilakukan untuk menghadapi kejadian - kejadian merugikan, sehingga dampak yang disebabkan kerena pengambilan keputusan dapat dihindari. Kegiatan penangkapan ikan laut, sangat perlu dilakukan proses manajemen risiko dalam menerapkan beberapa strategi untuk menjaga keberlanjutan usaha. Strategi preventif dilakukan untukmenangani sumber risiko produksi yang terletak pada kuadran 1 dan 2. Sumber risiko pada kuadran ini sangat berdampak pada usaha penangkapan ikan laut di Kota Bengkulu karena memiliki probabilitas yang besar.

Kurangnya modal melaut menjadi sumber risiko utama dalam proses penangkapan ikan laut di Kota Bengkulu. Sumber risiko ini berada pada kuadran 2, memiliki probabilitas dan dampak yang besar pada risiko operasional. Kurang modal melaut juga berdampak pada lama melaut. Padahal, lama melaut juga merupakan salah satu faktor penting yang mempengaruhi hasil tangkapan dan nilai hasil tangkapan yang pada gilirannya berpengaruh pada jumlah pendapatan nelayan (lihat penelitian Halim \& Susilo, 2013 dan Heryansyah, Muhammad, \& Syahnur, 2013). Termasuk dalam kuadran ini adalah cuaca yang tidak dapat diprediksi. Banyak penelitian yang membuktikan bahwa keadaan cuaca berpengaruh terhadap hasil tangkapan, di antaranya adalah Purnomo, Suryawati, Radjawane, \& Sembiring (2015) yang menyimpulkan bahwa peningkatan frekuensi ombak menyebabkan nelayan sulit menjangkau fishing ground. Strategi preventif yang dapat dilakukan pada kuadran ini hampir tidak ada, karena tidak ada sumber risiko yang berada pada kuadran ini.

Penempatan sumber risiko pada kuadran 2 merupakan risiko yang paling krusial. Kuadran ini ditempati oleh sumber resiko yang memiliki probabilitas besar dan dampak besar. Sumber risiko dalam kuadran ini harus segera ditangani, apabila dibiarkan saja maka pelaku usaha harus menanggung kerugian yang besar. Hal ini tidak terjadi pada jenis biaya operasional apapun. Dengan demikian, kegiatan yang dilakukan dalam penghindaran risiko produksi diharapkan akan terlaksana. Usulan strategi preventif berdasarkan kuadran pada peta risiko ini adalah memanfaatkan informasi cuaca seoptimal mungkin dan menabung atau menyimpan uang hasil usaha pada lembaga keuangan jika diperoleh hasil tangkapan yang berlebih.

\section{Strategi Mitigasi}

Mitigasi risiko merupakan kegiatan yang diharapkan dapat meminimalkan risiko yang terjadi akibat dari sumber risiko operasional. Strategi mitigasi risiko dilakukan dengan melihat dampak yang besar dari risiko operasional paling besar, yaitu risiko-risiko yang berada pada kuadran 2 dan 4 (Gambar 2). Sumber risiko yang berada dalam kuadran 2 tidak hanya ditangani dengan strategi preventif, namun dapat pula dilakukan dengan mitigasi risiko. Hal ini disebabkan, karena risiko pada kuadran ini sangat berarti bagi usaha penangkapan ikan laut di Kota Bengkulu. Kemungkinan risiko yang akan terjadi besar dan jika benar-benar terjadi akan menimbulkan kerugian yang besar pula. Sementara itu, kuadran 4 menggambarkan sumber risiko dengan probabilitas kecil dan dampak yang besar. Artinya pada kuadran ini, kemungkinan terjadinya risiko kecil akan tetapi 
jika benar-benar terjadi akan mengakibatkan dampak yang besar bagi pengrajin ikan kering baik dari sumber risiko operasional pada kesulitan permodalan maupun ketidakpastian hasil tangkapan. Oleh karena itu, strategi mitigasi risiko harus dilakukan pada kuadran-kuadran tersebut.

\section{Modal Melaut}

Permodalan merupakan syarat utama dalam menjalankan suatu usaha, tanpa adanya modal maka usaha apapun tidak dapat berjalan. Hal ini memicu harus adanya strategi yang dapat meminimalkan dampak terjadinya risiko tersebut. Sumber risiko yang terjadi pada kuadran 4, yaitu jenis biaya umpan dan solar. Ini juga mengindikasikan pentingnya nelayan untuk memaksimumkan hasil tangkapan Memaksimumkan hasil tangkapan akan dapat menutup biaya melaut di samping juga untuk persiapan melaut untuk periode melaut berikutnya. Salah satu strateginya adalah dengan menentukan daerah penangkapan ikan atau fishing ground dengan tepat. Ketepatan mencari fishing ground dengan memanfaatkan teknologi yang dapat diakses oleh nelayan menjadi penting. Salah satu alasannya adalah masih banyaknya nelayan di Kota Bengkulu yang masih menggunakan cara konvesional dalam menentukan fishing ground (Selvika, Mustaruddin, \& Yusfiandayani, 2019). Strategi ini juga dapat diikuti dengan perluasan pasar untuk hasil tangkapan ketika hasil tangkapan sudah mendarat. Asuransi bagi nelayan untuk memberikan perlindungan perlu diintroduksikankepada nelayan dalam bentuk bantuan modal kerja jika terjadi kegagalan dalam upaya penangkapan ikan.

\section{Nilai Tangkapan}

Penanganan risiko ketidakpastian nilai hasil tangkapan dengan cara mitigasi risiko hanya terdapat pada kuadran 4 . Nilai hasil tangkapan sangat bergantung pada jumlah hasil tangkapan dan harga ikan hasil tangkapan. Dua faktor ini di luar kontrol nelayan dengan faktor "luck" menjadi sangat dominan. Oleh sebab itu, strategi peningkatan jumlah hasil tangkapan dapat dilakukan dengan paling tidak empat strategi, yaitu (a) perluasan fishing ground yang tidak bergantung pada wilayah tradisionalnya, (b) ketepatan dalam mencari area pengkapan (fishing ground), (c) memperpanjang lama melaut yang memiliki konsekuensi meningkatkan modal melaut, serta (d) diversifikasi vertikal (hilirisasi) hasil tangkapan yang artinya ikan tidak hanya dijual dalam keadaan segar tetapi dimungkinkan untuk diolah lebih lanjut.

Secara umum, proses penanganan dengan mitigasi risiko adalah mengurangi dampaknya, yaitu dengan menggeser sumber risiko yang berada pada kuadran 2 akan bergeser ke kuadran 1 yang dampaknya lebih kecil meskipun probabilitasnya masih tinggi. Pada sumber risiko pada kuadran 4, strategi yang dilakukan adalah memindahkan ke kuadran 3 yang memiliki probabilitas kecil dan dampak kecil. Kuadran ini mendeskripsikan penanganan risiko mengakibatkan pengurangan dampak merugikan bagi para pengolah ikan kering. Strategi mitigasi risiko diharapkan mampu mengurangi risiko yang akan terjadi pada usaha penangkapan ikan laut di Kota Bengkulu.

Kuadran 3 merupakan kuadran yang berada pada posisi paling diharapkan memiliki titik aman (probabilitas kecil dan dampak kecil). Hal ini mendorong strategi penanganan risiko pada kuadran lainnya (kuadran 1, 2, dan 4) diharapkan dapat menuju ke kuadran 3. Pada strategi preventif dan mitigasi risiko, penanganan risiko adalah memindahkan sumber resiko ke kuadran 3. Namun berbeda dengan yang terjadi pada kuadran 2, strategi preventif dan mitigasi risiko hanya menyebabkan kuadran 2 berpindah ke kuadran 1 dan/atau kuadran 4. Kuadran 2 merupakan risiko yang paling krusial (memiliki probabilitas besar dan dampak besar), maka strategi penanganan yang harus dilakukan untuk mengubah haluan kuadran 2 berpindah ke kuadran 3 adalah dengan strategi kombinasi (pooling). Menurut Darmawi (1990), strategi ini adalah tindakan yang merupakan gabungan dari dua atau lebih strategi. Strategi ini baik dilakukan apabila langkah penanganan tidak membuat kompleksitas proyek berlebihan. Disimpulkan dari pendapat tersebut, strategi kombinasi dapat dilakukan dengan menggabungkan strategi preventif dan mitigasi risiko. Strategi ini diharapkan mampu menggeser posisi sumber risiko yang berada pada kuadran 2 ke kuadran 3. Penanganan dengan strategi kombinasi juga dilakukan agar sumber risiko pada kuadran 2 dapat menghindar dari kemungkinan risiko yang akan terjadi dan mengurangi dampak yang akan ditimbulkan oleh risiko. Oleh karena itu, perlu adanya strategi yang komprehensif untuk dapat memindahkan sumber resiko dari kuadran 2 ke kuadran 1. 
Dari setiap risiko hendaknya dapat merecanakan strategi mitigasi, agar dapat meminimalkan dampak risiko yang terjadi. Setiap sumber risiko pada usaha penangkapan ikan laut di Kota Bengkulu harus memiliki strategi mitigasi agar dapat meminimalkan dampak risiko yang terjadi (Tabel 5).

\section{PENUTUP}

Sumber-sumber kejadian berisiko pada usaha penangkapan ikan laut di Kota Bengkulu terdapat pada sumber risiko operasional dan risiko pasar, yaitu pada ketidakpastian hasil tangkapan, cuaca tidak dapat diprediksi, kesulitan permodalan, dan harga yang diperoleh tidak sesuai. Nilai probabilitas dan dampak risiko pada risiko operasional berdasarkan nilai tangkapan dan lama melaut, yaitu nilai probabilitas risiko operasional berdasarkan nilai tangkapan sebesar $32,64 \%$; risiko berdasarkan lama melaut sebesar $48,40 \%$; sedangkan nilai dampak risiko operasional berdasarkan nilai tangkapan sebesar Rp9.948.578,25. Risiko berdasarkan lama melaut, yaitu sebesar Rp528.221.990,08. Alternatif strategi yang dapat diterapkan oleh para pelaku usaha penangkapan ikan laut di Kota Bengkulu untuk menyikapi adanya risiko, di antaranya adalah (a) pemanfaatkan informasi cuaca seoptimal mungkin, (b) membiasakan menabung ketika hasil melimpah, (c) perluasan fishing ground di luar daerah tangkapan tradisionalnya, (d) ketepatan area pengkapan (fishing ground), (e) perpanjangan lama melaut, dan (f) diversifikasi vertikal (hilirisasi) hasil tangkapan.

\section{UCAPAN TERIMA KASIH}

Artikel ini merupakan bagian dari skripsi dengan judul yang sama pada Jurusan Sosial Ekonomi Pertanian, Fakultas Pertanian Universitas Bengkulu. Ucapan terima kasih disampaikan kepada semua pihak yang telah membantu terselesaikannya artikel ini, khususnya kepada dewan penguji skripsi. Ucapan terima kasih juga disampaikan kepada para nelayan yang ada di lokasi penelitian atas waktu dan kontribusi informasi sehingga tersedianya data penelitian ini.

\section{PERNYATAAN KONTRIBUSI PENULIS}

Dengan ini kami menyatakan bahwa kontribusi masing-masing penulis terhadap pembuatan karya tulis adalah Febi Yulianti sebagai kontributor utama, Ketut Sukiyono sebagai anggota dan penulis koresponden, serta Satria Putra Utama sebagai anggota. Penulis menyatakan bahwa telah melampirkan surat pernyataan kontribusi penulis.

\section{DAFTAR PUSTAKA}

Bahamid, R. A., Doh, S. I., Al-Sharafi, M. A, \& Rahimi, A. R. (2017). Risk Factors Influencing the Construction Projects in Yemen from Expert's Perspective. IOP Conference Series: Materials Science and Engineering, 712(1):1-7 Diakses dari https://iopscience.iop.org/article/10.1088/17 57-899X/712/1/012007/pdf

Base, C. (2016). Understanding Basic Statistics. Cengage Learning.

Tabel 5. Strategi Mitigasi Risiko Setiap Sumber Risiko.

\begin{tabular}{lcl}
\hline \multicolumn{1}{c}{ Sumber Risiko } & Kategori Risiko & Rekomendasi Strategi Mitigasi Risiko \\
\hline Ketidakpastian hasil tangkapan & Sedang & Perkirakan musim ikan \\
Cuaca tidak dapat diprediksi & Tinggi & Perlengkapan alat keselamatan \\
Kesulitan tenaga kerja & Sedang & Sesuaikan upah dan kerja \\
Permodalan & Sedang & Cari pinjaman dengan bunga terendah dan \\
& & Asuransi Perikanan \\
Lama waktu menangkap ikan & Sedang & Ketepatan lokasi fishing ground \\
Harga yang diperoleh tidak sesuai & Sedang & Perluasan pasar \\
Harga fasilitas produk naik & Sedang & Tambah modal \\
Banyak pesaing & Sedang & Tingkatkan kualitas berjual beli dan \\
& & perluasan pasar \\
Harga murah saat produksi banyak & Sedang & Olah ikan menjadi produk lain \\
Kerusakan ikan sehingga mutu produk rendah & Sedang & Hati-hati dalam menyimpan ikan \\
Permintaan pasar terhadap ikan rendah & Sedang & Cari partner sesama penjual ikan \\
Daya beli masyarakat menurun & Sedang & Pengurangan harga jual \\
\hline
\end{tabular}

Sumber: Data Primer Diolah, 2019 
Booker, F. (2005). Developing Effective Risk Management Strategies to Protect Your Organization. Risk Management Newsletter, July 2005 - Issue 5.

[BPP] Badan Pengusahaan Pelabuhan. (2018). Pelabuhan Pulau Baai. Bengkulu.

Chen, S., Chen, X., Cheng, Q., \& Shevlin, T. (2010). Are Family Firms More Tax Aggressive Than Non-Family Firms. Journal of Financial Economics. 95(1), 41-61 https://doi.org/10.1016/j. jineco.2009.02.003

Darmawi, H. (1990). Manajemen Risiko. Jakarta : PT Bumi Aksara

Darmawi, H. (2006). Manajemen Risiko. Jakarta : PT Bumi Aksara

Djohanputro, B. (2008). Manajemen Risiko Korporat. Jakarta: Pendidikan dan Pembinaan Manajemen.

Doherty, N. A., (1982). Integrated Risk Management Techniques and Strategies for Managing Corporate Risk. McGraw Hill. Inc. New York.

Ehsan, A., Denis, A. F., Kujur, F. E., \& Chaudhary, M. (2014). Risk Management Strategies for Accidental Risk Occurrence on Construction Sites-A Case Study of Allahabad. Journal of Academia and Industrial Research (JAIR), 3(2), 89 - 91 Diakses dari http://jairjp.com/ JULY\%202014/06\%20EHSAN\%20ALI.pdf

Fahmi, I. (2011). Analisa Laporan Keuangan. Bandung: Alfabeta.

Halim, D. \& Susilo, Y. S. (2013). Faktor - faktor yang Mempengaruhi Pendapatan Masyarakat Nelayan Pantai di Kabupaten Bantul Tahun 2012. MODUS, 25(2), 171-187 DOI: https://doi.org/10.24002/ modus.v25i2.561

Heryansyah, S., Muhammad, \& Syahnur, S. (2013). Analisis Faktor-faktor yang Mempengaruhi Produksi Nelayan di Kabupaten Aceh Timur. Aceh (ID). Jurnal IImu Ekonomi Pascasarjana, Universitas Syah Kuala, 1(2), 9-15 Diakses dari http://www.jurnal.unsyiah.ac.id/MIE/article/ view/4529/3904

Jorion, P. (2001). Value at risk: the new benchmark for managing financial risk. New York: McGraw-Hill

Kasidi. (2010). Risk Management. Jakarta: Ghalia Indonesia.

[KKP] Kementerian Kelautan dan Perikanan. (2018). Profil Potensi Usaha dan Peluang Investasi Kelautan dan Perikanan Provinsi Bengkulu. Direktorat Jenderal Penguatan Daya Saing dan Produk Keluatan dan Perikanan. Kementerian Kelautan dan Perikanan.

Kloman, H. F. (1992). Rethinking Risk Management. The Geneva Papers on Risk and Insurance,
17(64), 299-313. doi: https://doi.org/10.1057/ gpp.1992.19

Kountur, R. (2008). Mudah Memahami Manajemen Risiko Perusahaan. PPM. Jakarta.

Leal, D. R. (2008) A fishermen's agreement and co-op in Yaquina Bay roe herring. In: Case Studies in Fisheries Self-Governance (eds R. Townsend, R. Shotton and H. Uchida). Food and Agricultural Organization, Rome, pp. 415-423.Diakses dari http://www.fao.org/docrep/010/a1497e/ a1497e00.htm

Leung, P., Muraoka, J., Nakamoto, S. T. \& Pooley, S. (1998). Evaluating fisheries management options in Hawaii using analytic hierarchy process (AHP). Fisheries Research 36, 171-183. Diakses dari http://www.soest.hawaii.edu/PFRP/reprints/ leung_evaluating_1998.pdf

Lindawati \& Rahadian, R. (2016). Identifikasi Faktor dan Penilaian Risiko Pada Usaha Perikanan Tangkap di Kabupaten Sambas. J. Sosek KP. Jakarta Utara. 11(1): 99-107. DOI: http://dx.doi. org/10.15578/jsekp.v11i1.3175

Mullon, C., Fréon, P., \& Cury, P. (2005). The Dynamics of Collapse in World Fisheries, Fish and Fisheries, 6, 111-120. https://doi.org/10.1111/j.14672979.2005.00181.x

Prahestin, E. P. \& Harahab, N. (2018). Analisis Risiko Pembenihan Ikan Lele (Clarias SP.) di Unit Pembenihan Rakyat (UPR) Mulyorejo I Kabupaten Malang Jawa Timur. ECSOFiM: Journal of Economic and Social of Fisheries and Marine. . 05(02), 181-193 DOI:https://doi.org/10.21776/ ub.ecsofim.2018.005.02.07

Purnomo, A. H., Suryawati, S. H., Radjawane, I. M., \& Sembiring, K. O. (2015). Perubahan Iklim di Wilayah Pesisir. Konsep dan Aplikasi Strategi Adaptasi. Bandung (ID). Penerbit ITB.

Purwitasari, A. (2011). Manajemen Risiko Operasional pada Pemasaran Benih Ikan Patin PT Mitra Mina Nusantara di Kabupaten Bogor, Jawa Barat. Skripsi. Departemen Agribisnis. Fakultas Ekonomi dan Manajemen. Institut Pertanian Bogor.

Roy, A. D. (1952). Safety first and the holding of assets, Econometrica,20, 431-449. http://dx.doi. org/10.2307/1907413.

Selvika, Z., Mustaruddin, M., \& Yusfiandayani, R. (2019). Penentuan Fishing Ground dan Alat Tangkap Unggulan Ikan Pelagis di Kota Bengkulu. Jurnal Teknologi Perikanan dan Kelautan, 9(2), 137-147. doi: https://doi.org/10.24319/jtpk.9.137-147Sethi, S. A. (2010). Risk management for fisheries. F I $S H$ and $F$ I S HER I E S , 11, 341-365. DOI: 10.1111/j.1467-2979.2010.00363.x 
Siahaan, S. J. (2007). Pengaruh Tingkat Biosekuriti Terhadap Pemaparan Avian Influenza Pada Unggas Air (Studi Kasus Kontrol di Kabupaten Bogor dan Sukabumi). Bogor. IPB.

Sanchirico, J. N., Smith, M. D., \& Lipton, D. W. (2008) An empirical approach to ecosystem-based fishery management. Ecological Economics 64, 586-596. https://doi.org/10.1016/j.ecolecon.2007.04.006

Sukiyono, K. (2018). Penelitian Survai dan Teknik Sampling. BPFP. Universitas Bengkulu.

Tangke, U. (2011). Analisis Kelayakan Usaha Perikanan Tangkap Menggunakan Alat Tangkap Gillnet dan Purse Seine di Kecamatan Leihitu Kabupaten Maluku Tengah Provinsi Maluku. Agrikan: Jurnal Agribisnis Perikanan, 4(1), 1-13. doi: https://doi. org/10.29239/j.agrikan.4.1.1-13

Wardhono, W. (2005). Pengukuran Variabel. Jurnal Bina Ekonomi, 9(1), 12-28

Well-Stam, D. V., Lindenaar, F., Kinderen, S. V, \& Bunt, B. V. (2004). Project Risk Management: An essential tool for managing and controlling projects. London: Kogan Page

William, J. A. C \& Heins, R. M. (1985). Risk Management and Insurance. New York: McGraw-Hill

Zhang, W., Zhang, S., \& Zhao, P. (2019). On Double Value at Risk. Risks, 7(31), 1 - 22. doi: 10.3390/ risks 7010031 